\title{
Use of Digital Games in Writing Education: An Action Research on Gamification
}

\author{
Mazhar Bal \\ Akdeniz University, Turkey \\ ORCID: 0000-0001-6958-9130
}

\begin{abstract}
The aim of the study is to determine the contribution of gamification to writing skills of middle school students. For this study, a lesson plan has been developed to relate Writing and Authorship Skills lesson to the gamification for middle school students. From this lesson plan, it was tried to determine the effectiveness of the teaching process. Therefore, the study was designed as action research. The research group is composed of seventh grade students. Criteria sampling technique was used to determine the participants. As a data collection tool, student diary, semi-structured interview form, semi-structured observation form, digital content of the students were used. Data obtained from the semi-structured interview form were analyzed by content analysis; other data were analyzed by descriptive analysis. Writing skills and gamification were related in the study. Turkish Language Teaching Program (2018) has been taken into consideration in the action plan which relates to gamification and writing skill. As a result of the study, it was seen that all participants were actively involved in the implementation process. In addition, it was concluded that gamification increased the interest of students towards the course, combined school and non-school life, facilitated classroom management, supported collaborative work, and developed creativity. As a result of this study, it is suggested that digital games can be used as a text type in Turkish language lessons with the method of gamification in order to positively affect motivation of the middle school students toward writing education.
\end{abstract}

Keywords: Digital game; Writing skills; Gamification; Middle school students; Turkish language education

\section{Introduction}

Technology, as in many areas of the society, is felt in children's lives. One of the most noticeable effects of technology in children's life is the games. Until recently, games based on physical activity in more open spaces; has been replaced by the possibilities of the digital world (Hazar, Tekkursun Demir \& Dalkiran, 2017). These digital games became a worldwide market of about $\$ 100$ billion in 2016. Until 2019, this sector is expected to reach a size of 120 billion dollars. This sector, which has a large budget in economic terms, will reach a level of 128.5 billion dollars by 2020 (Newzoo, 2017). In Turkey, it was determined that 30.8 million people in 2017 have played digital games. These people spent $\$ 773.9$ million for games in 2017 (Newzoo, 2017).

It is inevitable that digital games that appeal to such a wide audience are reflected in education. Therefore, different studies have been conducted to use digital games in education. These studies reported that digital games develop cognitive skills (Homer, Raffaele, Ober, Plass \& Ali, 
2018), which itself facilitates vocabulary teaching (Chen, Tseng, \& Hsiao, 2018), and has an important function as a pre-organizer (Denham, 2018). Digital games also develop skills in solving problems (Rugoero \& Green, 2017) and collaborative learning (Sung \& Hwang, 2018). In addition, it is seen that digital games are generally used in the field of gamification and gamebased learning (Cózar-Gutiérrez \& Sáez-López, 2016; Karagiorgas \& Niemann, 2017; Khan, Ahmad, \& Malik, 2017; Nolan \& McBride, 2013; Pesare et al., 2016). Although these two types are different from each other, they are constantly mixed up (Prensky, 2007).

Game-based learning is the acquisition of knowledge and skills for the teaching process through games (Qian \& Clark, 2016 as cited in Bogott, 2017). Therefore, the tool through which the teaching process is carried out is as important as the teaching method (Piller, 2016). Gamification is associating the teaching process with game items such as badges, levels, and scores (Kapp, 2012). From this point of view, game-based learning is different from gamification in terms of the realization of learning. In game-based learning, the game itself is a learning platform (Kingsley \& Grabner-Hagen, 2018). In gamification, the game is an element to increase motivation. In the present study, the teaching process is related to gamification.

Another reason for the selection of gamification is the lack of literature. Existing research explores distance education (Sahin et al., 2017), biology education (Yapici \& Karakoyun, 2017), science language lessons (Sahin \& Namli, 2016), English language lessons (Polat, 2014), computer education (Ayhan \& Taner, 2016; Fis Erumit, 2016; Kalkan, 2016; Ozturk, 2015; Sari \& Altun, 2016), education at the undergraduate level (Yildirim \& Demir, 2016), and measurement and evaluation (Bolat, Simsek, \& Ulker, 2017; Taskin \& Cakmak, 2017). Literature-based review studies have also been carried out (Karatas, 2015; Kocadere, Caglar, \& Simsek, 2015; Ozgur, Cuhadar, \& Akgun, 2018; Sahin \& Samur, 2017; Sever \& Bical, 2018; Sezgin et al., 2018; Yildirim \& Demir, 2014).

It is seen that these studies have been published in the last two years. Most of the studies conducted are aimed at reviewing or determining opinions. In addition, there is a deficiency in implementation studies related to mother language education and gamification. As revealed in the study of Cibik (2010) on Turkish language education, the studies on remote activities are more abundant than those on digital media. Bal (2018) conducted a study related to digital gamification to determine teachers' opinions. Genc Ersoy (2017) conducted a study on fourth grade students to understand the use of gamification in the mother tongue education. In her work, she has taken gamification only from the point of vocabulary. Studies on the relationship between language arts and gamification have been determined to be generally related to second language education (Cruaud, 2016; Figueroa Flores, 2015; Gellar-Goad, 2015; Huner, 2018; Karatekin, 2017; Rachels \& Rockinson-Szapkiw, 2018).

Guasch et al. (2013) and Cook, Gremo, and Morgan (2017) found gamification to be associated with mother tongue education. These studies are not related to Turkish language education. There are no studies in which writing is associated with gamification in Turkish language education. This is argued to be an important deficiency because writing skills are the last in language arts and therefore a complex process for students (Demirel \& Sahinel, 2006). Students develop a negative attitude towards writing activities because they perform a complex and difficult process related to all skills in writing education (Maltepe, 2006; Ungan, 2007). This difficulty can be overcome with a content that can be done to the students with enthusiasm and willingness (Gocer, 2010). Among the seven reasons for writing, Tompkins (1982), who considers entertainment and encouragement, draws attention to the importance of motivation. In this respect, environments in which students can express themselves more than knowledge are 
important for writing education (Gocer, 2014). A writing process centering on students' feelings and experiences will also positively affect their motivation towards writing (Gogus, 1978).

It is thought that the increase in the motivation for writing education will contribute to the gamification by digital games because digital gamification contributes to the development of writing skill (El Tantawi, Sadaf, \& AlHumaid, 2018). Associating digital gamification with the writing process provides an active classroom environment and improves creativity (Hibbard, 2015). It encourages students to be open to innovation (Cahyani, 2016); develops problemsolving skills (Gee, 2013; Kapp, 2012; Kayalı \& Yilmaz, 2017; Ozer, Kanbul, \& Ozdamli, 2018; Urh, Vukovic, \& Jereb, 2015); supports collaborative learning (Buchinger \& da SilvaHounsell, 2018; Halloluwa et al., 2018; Sánchez-Martín, Cañada-Cañadave ,\& Dávila-Acedo, 2017). In addition, the students are motivated to write (Gee, 2008; Kingsley \& Grabner-Hagen, 2015; Lam, Hew, \& Chiu, 2018; Olson, 2010; Ozer, Kanbul, \& Ozdamli, 2018).

The Turkish Language Curriculum (2018) can also be used as a reason for the use of digital gamification in writing education. In the current Turkish Language Curriculum (2018), which was renewed in 2017, unlike the previous Turkish Language Curriculum (2006), crucial innovations have been introduced in terms of text types. The renewed program includes texts that are part of the students' daily life such as blog, e-mail, news, advertising, social media messages, comics, cartoons. It is thought that these texts will have a positive effect on students' attitudes towards Turkish course. In addition to these texts, it is known that digital games have an important place in students' daily lives, but it not included in the program. From this point of view, it can be said that digital games may be useful in increasing motivation especially for writing education.

Based on these explanations, it is thought that digital gamification is important for students to feel comfortable in the teaching process and to be associated with writing activities in-school and out-of-school. It is considered to be useful in terms of the development of writing skills in a fun way. In addition, it is assumed that gamification will be beneficial for students to feel belongingness to the lesson while developing their writing skills. In this context, the study aims to determine the contribution of gamification to the writing education of seventh grade students. Unlike the studies in the literature, this study has prepared an action plan on how digital gamification can be associated with writing skills. A content was presented in this action plan about how to use digital games that are not recommended in Turkish Language Curriculum (2018) but which are thought to have an important place in their daily lives. In this way, it has been investigated whether the negative motivation of the students that is emphasized in the literature have changed or not. The following research questions were investigated in line with the purpose of the study and the action plan:

1. How is the implementation process for the use of digital gamification in developing writing skills?

2. What are student views on how digital gamification affects motivation for writing?

\section{Method}

\section{Research Model}

A lesson plan was developed for the 7th grade students to relate Authorship and Writing Skills lesson to gamification in this study. Based on this lesson plan, which focuses on the contribution 
of gamification, the effectiveness of the teaching process has tried to be determined. Therefore, the study was designed with action research. Although studies were conducted in different areas, action research was used to improve the effectiveness of the educational process (Baker, Davis \& Dolgon, 2014; Cammarota, Romero, \& Stovall, 2014; Ferguson, McNiff, \& Whitehead, 2000; Fettes, 2007) because action research is a design that teachers do research and implement it to make their teaching processes more efficient (Stringer, Christensen, \& Baldwin, 2010; Zireva, 2017). In this regard, action research is also known as teacher research (Cohan \& Honigsfeld, 2011; Vaughan \& Burnaford, 2016).

In this study, it is thought that action research is the most appropriate design since it is aimed to determine the contribution of digital games to writing skills of the seventh grade students. In this respect, it was designed with action research to make the teaching process more effective. In accordance with the quality of the action research, a problem that is thought to exist in education has been presented, a solution proposal has been presented and the implementation of this solution proposal in class activities has been tried to be determined. The underlying problem of this action research was the low motivation of middle school students for writing education. It is known that the games have an important place in the students' out-of-school life; however, there is no content in the Türkish Language Curriculum (MEB, 2018) that relates gamification and writing skills. In addition, there are deficiencies in the studies related to gamification and writing education. Therefore, the low motivation for the 7th grade students' writing skills are presented as the solution can be improved with digital gamification. In this context, it has been tried to make writing education process more interesting for students. An action plan was prepared in line with this problem and solution proposal.

This plan has been carried out in the following stages, taking into consideration the relevant research (Johnson, 2005; Kemmis, McTaggart, \& Nixon, 2014; McNiff \& Whitehead, 2006; Tomal, 2003): (1) The problem of digital gamification and writing skill was explained, (2) the research was based on a six-stage model of Werbach and Hunter (2012), (3) an action plan was prepared before the data collection process was started, (4) data were collected and changes were made to the teaching process where necessary during the data collection process, (5) data were analyzed, (6) reporting, (7) results, discussions and suggestions were written.

\section{Research Group}

The research group comprised of seventh grade students. The criteria sampling technique was used on the basis of the selection of participants. We set the criteria according to the literature (Yildirim \& Simsek, 2013). The most basic criterion was determined by the Turkish language teacher, who will perform the practice, to have problems with low motivation of the students while performing the writing education. It is among the criteria that the school has sufficient technological equipment for gamification and that the teacher is the field expert (master's degree). The reason for searching the field expert criterion is that the action plan is intended to be applied to the Turkish language teacher. It was tried to make students feel more comfortable and thus the data collection process was carried out in a healthier way. In addition, school administrators and parents must approve the research, and the Turkish language teacher must follow the proposed lesson plan throughout the application process.

Thirty qualifying schools from a city situated in the Mediterranean region of Turkey were invited to participate in the study. Among these schools, two met all the criteria. One of these schools was eliminated because one of the the teachers had already worked on multimodal texts. In this 
school, the Turkish language teacher is a domain expert handling the Authorship and Writing skills lesson for the seventh grade. Therefore, the research was conducted with 12 students ( 7 females and 5 males). In fact, there are a total of 15 students in the class but these students were not included in the study because they did not want to participate in the data collection process. For the male students, the cover names Mehmet, Demir, Seref, Ercan, and Orhan were used. For the female students, the cover names Emine, Gulhan, Ayse, Tulay, Aysenur, Yuksel, and Aydan were adopted. Covernames were used for ethical purposes.

\section{Data Collection Techniques}

Different data collection tools were used to increase the validity and reliability of the study (Johnson, 2014). Information about the development process of the data collection tools is presented as follows.

\section{Student Diary}

The 12 student participants served as the source of this data collection tool. In applying this tool, the students were asked to answer five open-ended questions. These questions were aimed at determining what the students learned and how they felt about their lessons. Daily forms were distributed at the end of each lesson. Through the diary entries, student observations and reactions to the lessons (Yildirim \& Simsek, 2013) were obtained. Daily entries were made voluntarily. Exactly 87 diary entries were collected during the research process.

\section{Semi-Structured Observation Form}

An observation form was prepared to support the research process with different data sources. During the preparation of the form, the following steps were followed. Seven questions were prepared with consideration of the aims of the research. The questions were submitted for approval by the domain experts who examined the questions in terms of content and construct validity. The questions were reworded according to the feedback of the field experts. The number of effective questions was reduced. The final form comprised four questions, which were submitted to the domain experts for review and approval. Finally, the pilot study was implemented to evaluate the observation form in terms of comprehensibility. The pilot study was conducted with six students (three females and three males) from the original pool of participants. After the conduct of the pilot study, the points that made the form unclear were addressed, and the final form was prepared. The questions focused on how the teaching process is carried out, the emotional reactions of the students to the course, and the applicability of the action plan. The researcher served as the source of this data collection tool. Eight observation forms were collected during the research process.

\section{Semi-Structured Interview Form about Views on Turkish Language Lesson}

This data collection tool was developed to identify the participants' views toward their writing experiences associated with digital gamification. When the form was developed, the following steps were taken sequentially. Five questions were prepared in consideration of the research purpose. The questions were submitted for approval to three domain experts who evaluated 
them in terms of content and construct validity. The number of questions was increased to six based on the feedback of the domain experts. A pilot study was conducted to determine the suitability of the questions for the target group. For the pilot study, six students (three females and three males) were selected out of the research population. The group selected for the pilot study exhibited the same characteristics as the participants of the main study. The points that made the interview form unclear were arranged according to the feedback from the pilot study. In this way, the form was finalized. The semi-structured interview comprised six questions, which focused on topics to be learned in the research process, opinions about the research process, opinions about the web 2.0 tool, and opinions about digital gamification. This form was disseminated to the students. Therefore, 12 interviews were conducted.

\section{Digital Texts Produced by Students}

The participants served as the source of this kind of data. The participants created digital texts through the web 2.0 tool called Storium. Storium (https://storium.com/) is a writing tool. With its unique features, this tool encourages collaborative writing. Offering the opportunity to write on different topics without limiting one's imagination, this tool also offers entertaining experiences with digital gamification elements. Detailed information about Storium is presented in the discussion about the first research question. As the application is programmed for collaborative writing, three groups of users were created. Four groups were available in total. Each group produced its own text, and thus, four sets of text were obtained.

\section{Data Collection Process}

The research process took a total of 12 weeks. The study was conducted on the Authorship and Writing Practice lesson for two hours a week. The research process started on November 8, 2017. The teaching process was carried out according to the six-stage gamification model of Werbach and Hunter (2012). The phases of the model according to the implementation process were as follows:

(1) Identifying the targets: This step represents the main objective. The main purpose of this study is to determine the contribution of gamification in terms of motivation to the writing process. (2) Identifying target behaviors: This phase refers to the determination of the behaviors necessary to achieve the main goal. The target behaviors of this research are the writing achievements under the Turkish Language Curriculum (2018). The participants were expected to act accordingly. (3) Determining the type of player: This stage refers to the separation of the duties and responsibilities of the participants in the digital gamification process. The players in this study were of two types. The first type comprised the narrators, and the second type comprised the players. The duties of the narrators and players are discussed in details in the Results section. (4) Designing the activity cycle: This phase involves the implementation of the digital gamification process. The key users of the digital gamification process in this study were the narrators. Their story served as the basis of the main game. The players contributed to the narrators' fictional story by using their own imagination. In general, the narrators opened the game during the digital gamification process, and the players made their moves accordingly. (5) Adding fun items: This phase refers to the fact that the digital gamification process includes fun elements for the players. The entertainment element of this work is that players make their moves by using their own strengths against difficulties and that the writing process takes place in a digital environment. In addition, it consists of a three-stage process in which students move 
forward and their ranking according to the scores of students for each stage constitutes the elements of entertainment. (6) Identifying appropriate tools: This stage refers to the digital tools through which the digital gamification process can be carried out appropriately. A single application was used in this study. The reason for selecting this application was based on writing and digital gamification. Ease of use among members of the working group was also a main consideration. Web 2.0 tool's name is "Storium".

Information about Storium and how this tool is used in the implementation process is presented below: (a) Introduction to the application: Storium is an online application that integrates the digital authoring process with digital gamification. The application only has the English language option. The participants were all part of the first lesson. Membership to the application is free of charge. (b) Setting up a game: Each user first enters the game from the "Game" tab on the main page. At this stage, the users create a theme and choose an avatar. The game is played with at least two users. One user sets up and directs the game as the "narrator." The other user serves as the "player" and plays the game set up and directed by the narrator. The narrator sets up a game by entering and setting all the details in a section called the "green room." In this section, the narrator can make the game open to everyone. At this point, users from many parts of the world who use this application can join the game. In addition, the narrator can make the game open only to selected players. The game can either send an e-mail to selected users or add them using their usernames. For this study, the narrator sets up the game and targets selected users. The narrator identifies the hurdles and convenience cards to be used for the game. The narrator then adds the players to the game. (3) Character creation: The narrator sets up the game in the section called the "green room." The first step in building a game is the creation of the narrator's own character. At this stage, the application asks the user to define the character by features such as profession, weaknesses, and strengths. This setting completes the character creation process. The players also create their own characters in the same way. The particular characteristics of the players influence the future stages of the game. Through the weak and powerful features of the players, they are able to deal with obstacles that need to be overcome when making moves. (4) Starting the game: At this stage, the narrator and the players are ready to play. This process consists of three parts: introduction, development, and results. The whole process is guided by the narrator. The narrator opens the game with a story of his own choosing. The narrator writes the introduction of the story. The length of the paragraph is determined by the narrator; no specific limitation was set for the study. After the entry of the story is established, the players take action. The move that each player must make is to complete the story, but this task is not simply about writing. At this stage, digital gamification elements come into play. After the narrator plays the game, the player puts a few obstacles that must be taken into account when making a move. This barrier is divided into two. One barrier includes the operational difficulties, such as the condition of performing a difficult operation. This process has to be completed by the player while moving. The other barrier involves the character who makes the process of making a move difficult. The difficulty or desire of this character must be determined when making a move. Players enter the difficulties section before making moves and then make moves by choosing the difficulty level appropriate to their characteristics. Each player has to choose a different difficulty level. In this process, the narrator can make the players' job easier by offering a so-called "asset card." If the "target card" is inserted into the nominated element, the player can know what to do. The player then moves at the set difficulty level with help from the narrator. Then, the process is repeated. The narrator brings more of the story according to the players' moves. In this way, the same process is repeated. (5) Ending the game: At the end of each episode, the narrator can be informed about the level of understanding of the players. If the players overcame all the difficulties using their powerful features, they were deemed to have successfully completed the relevant part of the story in accordance with its 
purpose. If they used their weak features, they were forced to do so with difficulty. In this case, the narrator may extend the story to serve the story's purpose. If the weak and powerful features were equal, predicting whether the players served the story's purpose is difficult because it means that the players reached this level by using their presence and target cards. In this case, the narrator may proceed to the relevant section.

The narrator can keep each part of the game consisting of three parts as long as necessary. After the players make their moves, the narrator can finish the part and move on to the next part. The only requirement for this process is the completion of all the challenges presented by the application for each part. If the difficulties are not complete, the narrator must write the end of the story to establish a conclusion. The other part can be switched in this case.

The research process, which was carried out according to the aforementioned steps, generally consisted of three parts, as described below.

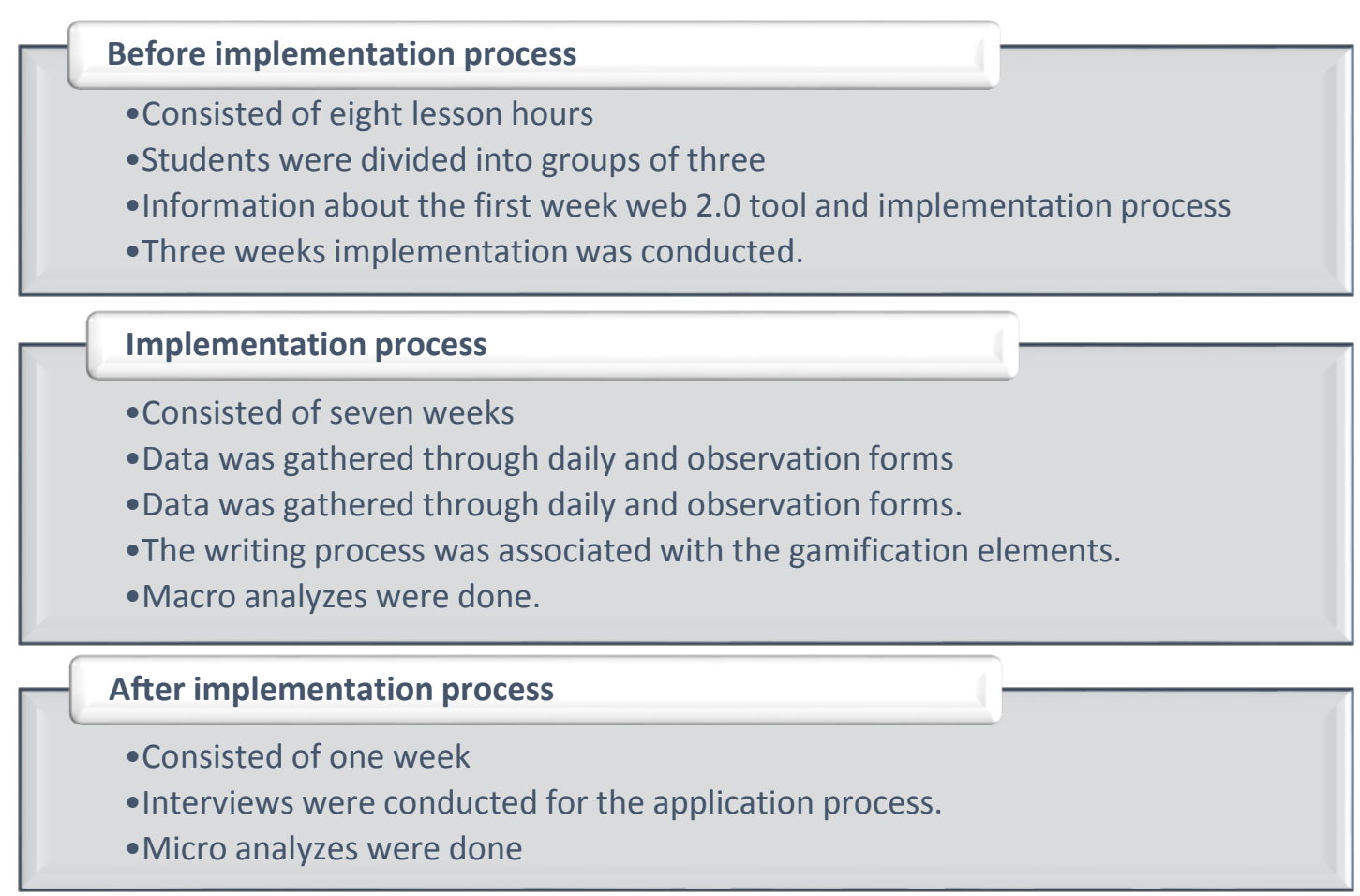

Figure 1. Implementation Model

As can be seen from Figure 1, the students were informed about the contents of the application in the first week. A total of four groups ( 3 members in each) were formed. The writing process associated with the game was implemented between December 7, 2017 and January 18, 2018. The semi-structured observation form, student diaries, and digital texts were collected during the implementation process. Between January 18, 2018 and January 25, 2018, the students' opinions were collected through the semi-structured interview form.

\section{Data Analysis}

The data on the first research question (semi-structured observations, student diaries, digital texts) were analyzed descriptively. The descriptive analysis technique was selected to present 
the implementation process in stages. In the analysis of the data on the second research question (semi-structured interview form), the content analysis technique was used to present the data in details.

As the analysis of data in the qualitative research process was performed simultaneously (Creswell, 2013; Merriam, 2013; Patton, 2014), it was carried out in two stages. In the first stage, all the data gathered during the implementation process were analyzed through macroanalysis. The macroanalysis results were regularly presented to the validity committee every week. The validity committee consisted of three domain experts. They contributed to the fulfillment of the action research cycle and to the analysis process. In the second stage, all data were analyzed through the microanalysis technique at the end of the application period. All data were then transcribed. A qualitative data analysis program was used when the data were transcribed. The result was presented to a domain expert to confirm that the data were transcribed correctly. The domain expert confirmed the coherence of the raw version of the data and the transcribed version. Analyses were then carried out. The final results of the analyses were compared with those of the microanalysis and the previous macroanalysis. The same data were also coded by another domain expert. Coding reliability by two participants was determined to be $90 \%$ and this was considered sufficient (Miles \& Huberman, 1994, 64).

\section{Validity and Reliability of the Study}

All data obtained in the research process were analyzed without any changes. The validity and reliability of the study was confirmed by the validity committee at every stage since the beginning of the research process. In order to increase the validity of the study, we employed the following headings according to the work of Lincoln \& Guba (1985).

Credibility: A long-term application period (12 weeks) was designed to ensure the credibility of the research. With this time period, the students were granted enough time to complete their task. In addition, the practice was carried out by the teachers to catch the students' natural reactions.

Transferability: For transferability, we detailed how the implementation process should be conducted. In this regard, another researcher tried to provide the opportunity to do the same study.

Trustworthiness: The research process was carried out with four different data collection tools. Detailed information on the validity and reliability of these tools is provided in the Data Collection Tools section.

Confirmability: The research process was not based on the data obtained from a single data source. Research observations were also included in the process. Different data sources were presented in the report of the researcher. Direct references were also utilized to embody the results.

\section{Results}

This section was based on information about the implementation process of the action plan. Since action research was based on an intervention program, this part describes in details what 
was done during the implementation process. The part was grouped under one heading but the research questions were based on two stages. In the first phase of the report, how the writing process associated with gamification was performed is explained. In the second stage, there were findings related to student views on the implementation process. While the two research questions were given, no separate titles were opened. Both were given under the same heading so as not to interfere with the fluency of the implementation process.

\section{Results Related to the Research Process}

This section provided information on the implementation process carried out for 12 weeks. The application process for the Authorship and Writing Skills course was carried out two hours a week. Information about each week's implementation process was summarized before the end of the seven-week implementation period. This information included the contents of the implementation, the contents of the diaries collected at the end of each lesson, and the writing tool (Storium). After explaining the steps of the implementation tool named Storium which was described in detail in the data collection process, the researcher gave information about the responsibilities expected from them in this course. The responsibilities of teachers, narrators and players throughout the implementation process is as shown in Figure 2:

\section{Teacher Responsibilities}

- The first three weeks played the role of narrator of the process. During this threeweek period, students were provided with the pre-information needed by the students in the gamification process.

-In the next seven weeks, he guided each group's narrator and players.

-While taking guidance, the Turkish Language Course Curriculum (2018) was taken as a citation. The information about these achievements were given in the responsibilities of narrators and actors.

\section{Narrator Responsibilities}

-The writer determined the appropriate title for the topic. They wrote short text, paying attention to the steps. They asked questions about the text. They organized the text in terms of meaning, writing and punctuation. They shared what they wrote in practice.

\section{Player Responsibilities}

-Before they made the move they fulfilled the following responsibilities: "They defined the theme of the text, the main idea, the helping ideas, the elements of the story. They interpreted the content of the text and determined the perspective of the narrator to the events. They produced different solutions to the problems handled in the text.They were found in conclusions about what they read. They have grasp of process steps in the text. They read those instructions."

-In doing so they fulfilled the following responsibilities: "It was asked to make their move from the text of the game builder. They took those steps into account when they made a move. They used a language that was free from foreign languages. They used connection expressions. They were careful not to make mistakes in spelling and punctuation; they corrected the mistakes. After they made corrections they made their moves."

Figure 2. Responsibilities of Participants 
As shown in Figure 2, the responsibilities of the narrator and players were determined according to the writing learning outcomes of the Turkish Language Curriculum (2018). Each of the above responsibilities represents a writing learning outcome. The learning outcome codes that the narrator fulfills were T.7.4.6., T.7.4.11., T.7.4.12., T.7.4.16., T.7.4.17., and T.7.3.19. The learning outcome codes of the players were T.7.3.16., T.7.3.17., T.7.3.18., T.7.3.21., T.7.3.22., T.7.3.24., T. 7.3.28., T.7.3.38., T.7.4.4., T.7.4.6., T.7.4.9., T.7.4.15., T.7.4.16., and T.7.4 .17.

After the information within the first three weeks was obtained, the process in which the students signed up as players and the teacher signed up as a narrator was implemented. This process is depicted in Figure 3.

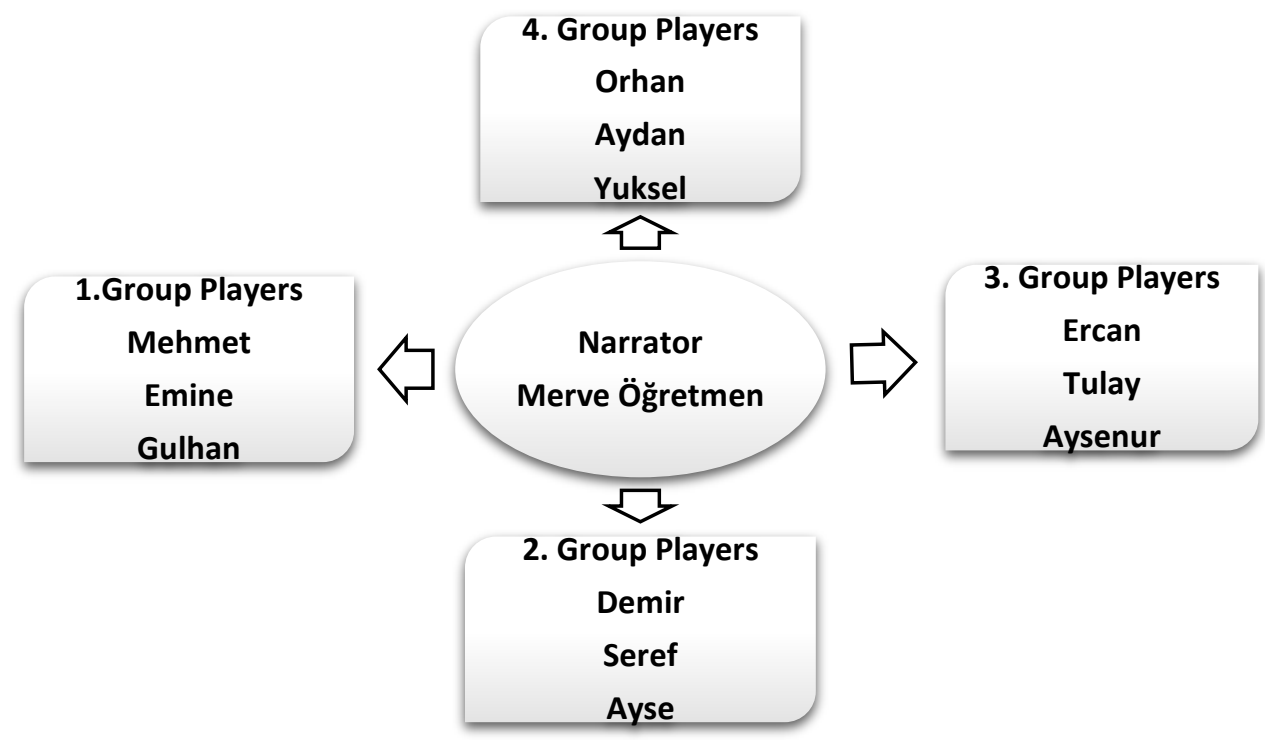

Figure 3. Task Diagram

At this stage, the teacher started the research process. As shown in Figure 3, each group participated in the game by opening a common account. The groups evaluated together the obstacles and opportunities that the narrator presented to them before they made their moves. The story of the narrator was decided and played by the participants together. The relationship between the writing process and the Turkish language lesson was reflected in the diary of some of the students.

"I think that such a lesson is necessary because the things learned are more mindful and allow us to work together because we are doing group work. It's more fun than any other work." (Demir, diary form)

"I think such a lesson is necessary because it increases both socialization and creativity" (Emine, diary form)

"I think we made a lot of fun activities in class. I think we made the necessary course games because we learned to have fun and to write a story." (Aysenur, diary form)

As it was understood from the opinions, the application developed creativity, made the teaching process fun, and emphasized socialization. The most important point made by the students in the first week was that the application provided a suitable environment for group work. These opinions were further reflected in the following diary entries. 
"In the lesson, I learned how to use Storium and collaborate while writing a story." (Emine, diary form).

"I've never used Storium before. I used it for the first time and loved it very much. We worked together, and we consulted each other." (Aydan, diary form).

"Yes, I learned new things about the game. For example, there is a topic to think about and learn by working in groups. Most importantly, we did group work by listening to our friends' speech." (Seref, diary form).

According to the comments, the students had never used Storium before. Nevertheless, the first lesson helped the students understand the main features of the program through the collaborative writing process. These positive comments for the first week reflected in the diaries of the students are supported by the observation data.

"Today's children are attracted to this activity because they are open to technology and have increased interest and desire for the lesson. It also raised their motivation toward the lesson. They expressed that they had more fun and became curious. They were quite willing to participate in the activity. They constantly asked questions about the application in a curious way." (Investigator, semi-structured observation form)

After this first week of the application, the teacher served as a narrator again for two more weeks. In this three-week period, the teacher, as the narrator, made the students understand the digital gamification process. Each group was divided into four subgroups. Each subgroup made the decision to coordinate the narrator's story before making any moves. At the end of this three-week period, the students' belonging to the implementation process shared their reflections in the observation form.

"The students felt like themselves in the classroom. They commented about the game from the WhatsApp group we created and asked questions." (Investigator, semistructured observation form)

The interest of the students in the implementation process was also determined in the observation form. With this process, the students gained knowledge about the implementation process. Along with this transition process, the students became accustomed to the activity. Those with experience in the implementation process switched to the main implementation. The group members and their responsibilities in this part of the implementation are shown in Figure 4. Each group was re-tasked to have one narrator and two player, the identities of which were determined by the participants. Who would be the narrator and the player is left to the opinion of the participants.

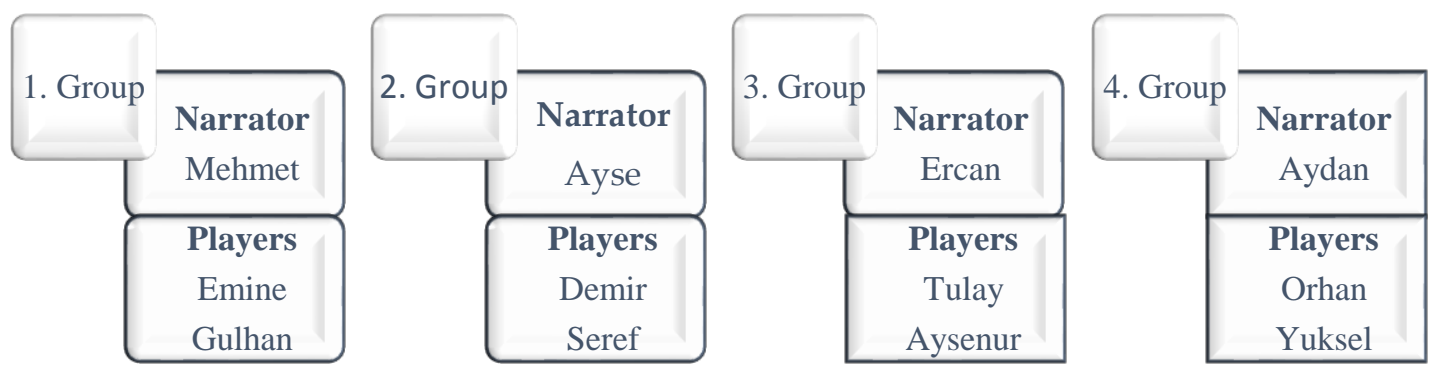

Figure 4. Task Distribution for the Main Application 
The narrators (Mehmet, Ayse, Ercan, and Aydan) shown in Figure 4 created their cards during the first two weeks. The players created their cards for the strengths and weaknesses that they thought would make their job easy when making a move. As sharing the information from all groups was bound to be complex, it was selected a single group as an example for the implementation process. Figure 5 shows the strengths and weaknesses of the group members.

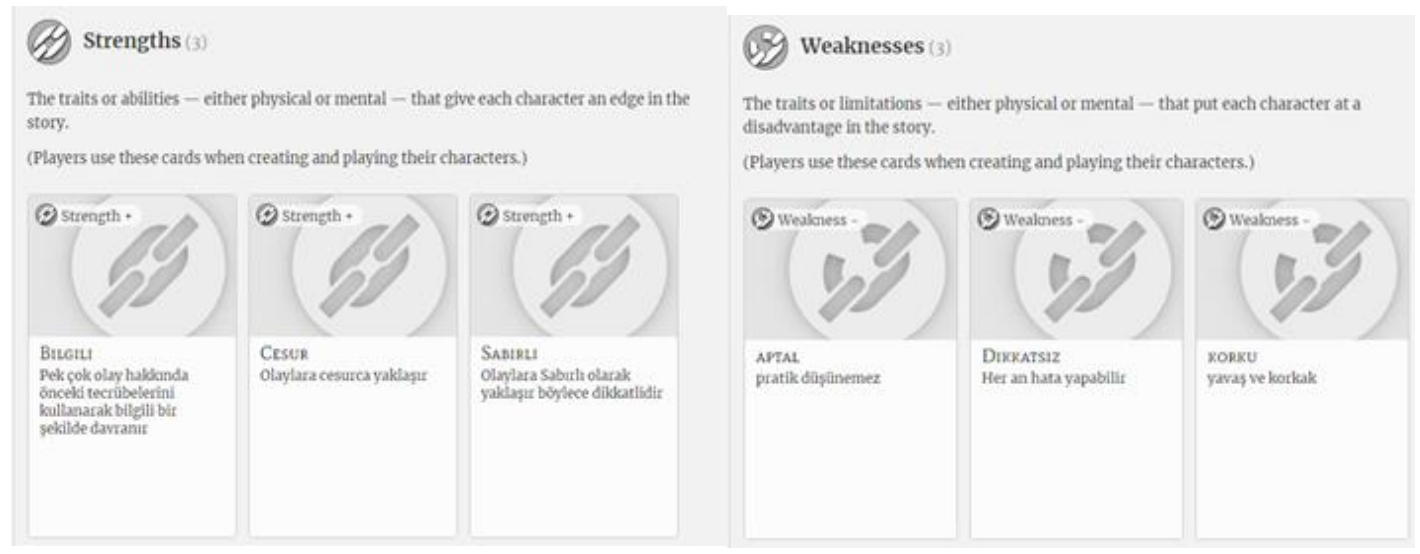

Figure 5. Example of Strengths and Weaknesses of Group Members

As seen in the example in Figure 5, the members of the group formed their own cards about their strengths and weaknesses. While they created these cards, the application imposed no restrictions. The participants were asked to reflect on how they see or describe themselves in real life. While the players prepared their cards, the narrators prepared their own cards. Each narrator developed difficulty cards and asset cards, taking into account the content of the game. Figure 6 presents the difficulty cards prepared by a narrator.

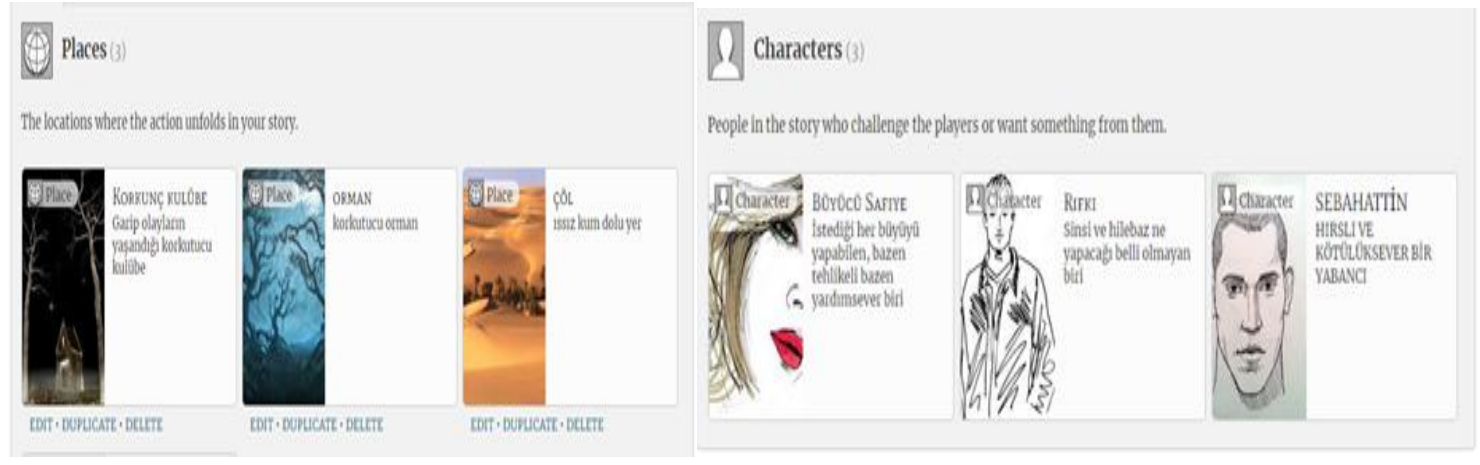

Figure 6. Example of Difficulty Card

As shown in Figure 6, the narrators identified two different difficulty cards. One referred to the place of difficulty, whereas the other referred to the difficulty to be handled. According to the flow of the text, the players made their moves by selecting these difficulties, but in the beginning, the narrator prepared the cards. The cards were prepared according to the content of the text. When the players chose one of these cards during the game and made a move, they could not choose another player. Another important feature of these cards is that they served as a criterion for ending the game. The game could not be completed without completing the difficulty cards. The narrators formed asset cards following their development of the play cards. Figure 7 shows an example of an asset card. 


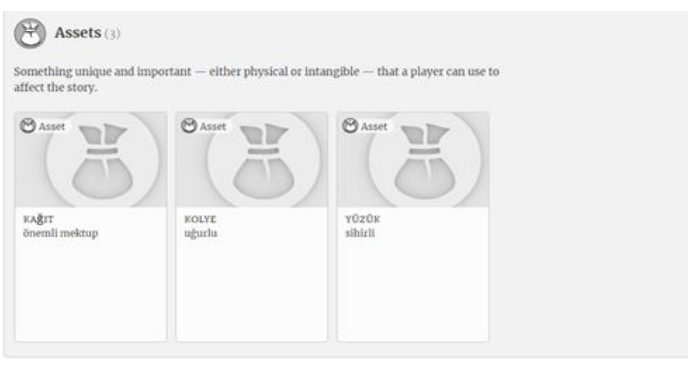

Figure 7. Example of Asset Card

The asset cards in Figure 7 are generated by the narrator. If the player was forced to make a move, the narrator could provide the player with an asset card. The narrators in this study provided their reflections via the two-week process observation form.

"When they learned the functions of the narrator and player cards, each student created an example of their own tablet. They were interested and entertained." (Investigator, semi-structured observation form)

The card-making process seemed to generate interest in the teaching process. The players and narrators who completed the necessary preparations for the digital gamification process advanced to the writing process. This process lasted five weeks. At the beginning of this fiveweek period, the narrators started the process of digital gamification with the subject they identified. Examples of the subject of the narrator are shown in Figure 8.

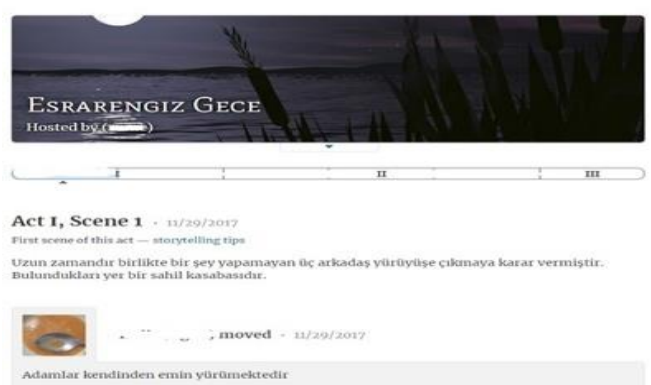

Figure 8. Examples of a Subject for the Initial Stories of the Narrator

As shown in the example, the narrators set a story for the digital gamification process. The title of the story was "Mysterious Night," and the setting was a seaside town. The narrator told the following story: "Three friends who have been unable to do anything for a long time have decided to go for a walk. The place they're in was a seaside town." Then, the narrator asked the players to complete the story without disturbing the flow. When narrating the story back, the players made moves by solving the pre-determined difficulties (see Figure 9).
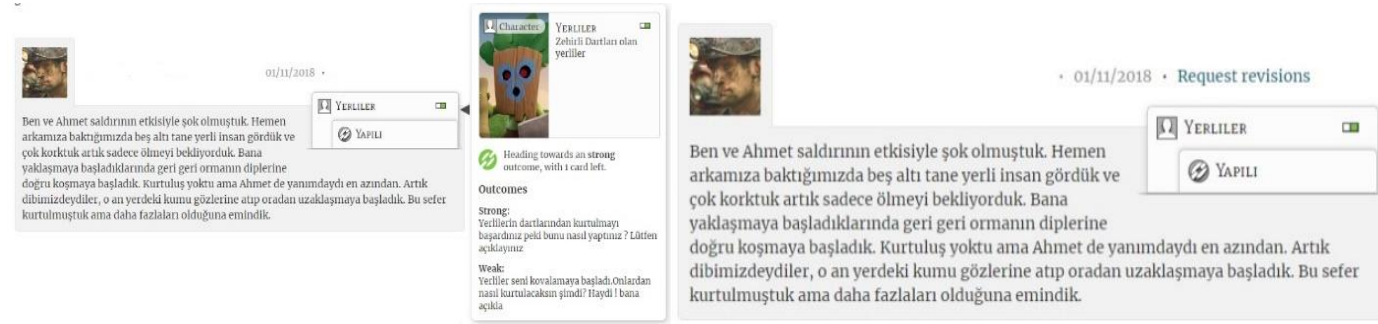

Figure 9. Example of a Move against Difficulties 
The two screenshots in Figure 9 are the same. The first screenshot was visible in the interface of the application. The "locals, structured" words on the top right corner of the screenshot were the pre-established obstacles. The players chose one of these obstacles predefined by the narrator according to their own characteristics and then proceeded to make a move for the game. In the second screenshot, this obstacle was explained, along with the requirement of the narrator. The players clicked on these words during the move to see the requirement. Some of the students' views on these obstacles during the game were reflected in their diaries.

"We made individual groups. When we created the characters, we entered a complete knot." (Orhan, diary form)

"I learned to write a story and to be careful when writing a story." (Gulhan, diary form)

"Yeah. I learned to choose obstacles in Storium and to bring the story to the end according to that obstacle. I also learned to publish and comment on it." (Ayse, diary form)

Evident in the diaries, the story in the writing process expanded against the obstacles. The students also experienced problems in the story writing process. Moreover, the problem-solving abilities of the students developed at this level. A sample text of the authoring process, in which each player faced other players with the same difficulty, is shown in Figure 10.

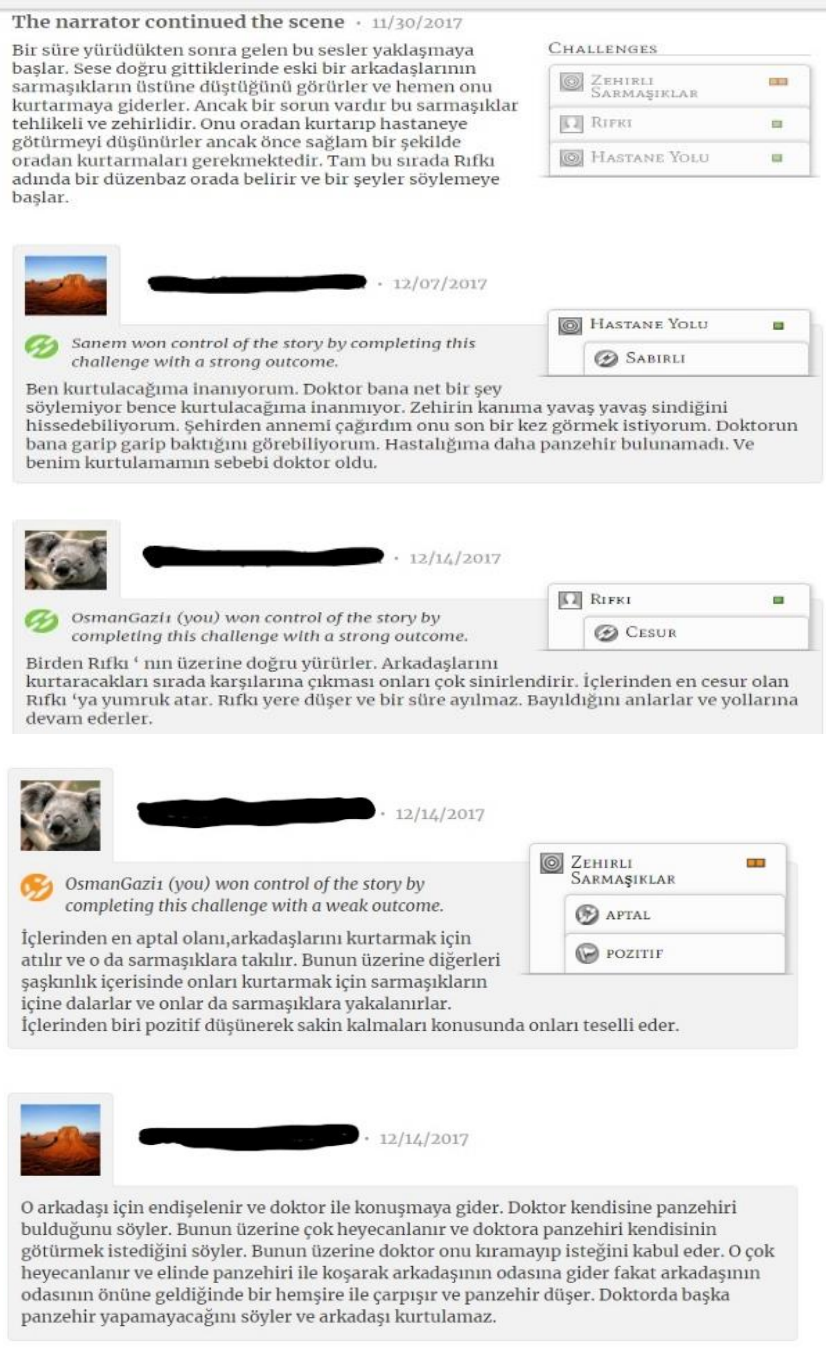

Figure 10. Story Writing Process and Moves 
As shown in Figure 10, the students completed the writing process. The students competed against one another according to the movements they made while writing the story. The program listed them according to their strengths or weaknesses and according to the obstacles they faced. During the process, the students were able to gain an overview of their situation according to the graph shown in Figure 11.

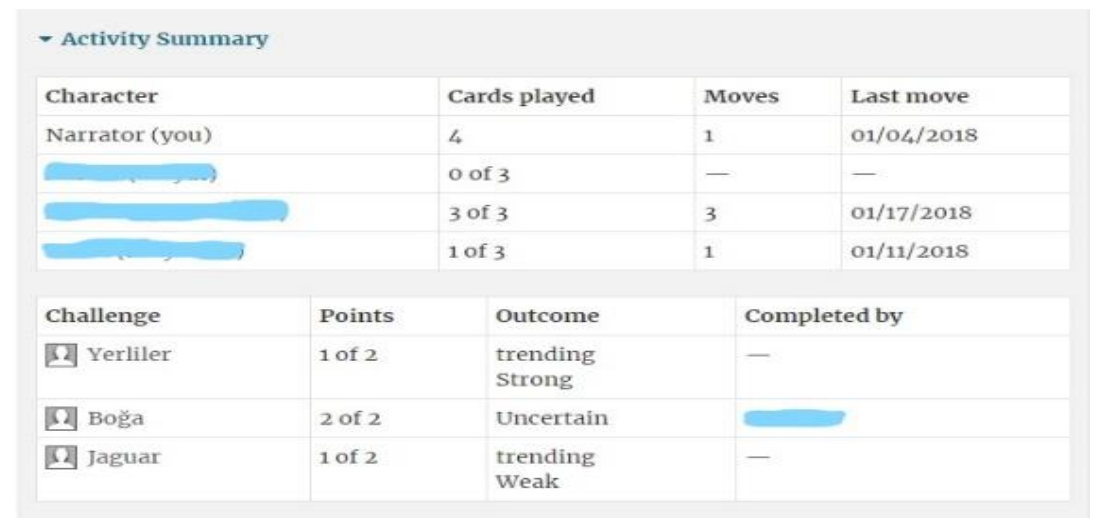

Figure 11. Student Graph

Figure 11 shows the number of moves the players made and which properties their moves exceeded. At the end of each chapter, the players held information about their own situation. Thanks to this information, the players could learn about their success in the game. They noticed the features that put them ahead of other players. From this point of view, the application was especially important in the process of digital gamification. At the end of the implementation period, the participants' discontentment was reflected in their diaries.

"I felt bad leaving the lesson because the lesson never ended."(Aysenur, diary form)

"Actually, it's a little early today because I was having so much fun; so, I was sad." (Demir, diary form)

"I feel a little sad leaving the lesson because it is very short and happened only once a week; this makes me sad." (Seref, diary form)

The students clearly felt a sense of belonging to the lesson. The information about the last lesson of the application process, which was thought to be addressed to their world, was reflected in the observation form.

"We had a lot of will and fun during the whole semester. We closed the semester with positive exchanges of interest. They are quite interested. They are sorry that this is the last lesson. They even offered to play together after the lesson." (Investigator, semistructured observation form)

When they came to the end of the implementation period, the students expressed their unhappiness toward having to end the lesson. Those with such views were interviewed. The purpose of this interview was to determine the opinions that the implemenation process served the writing education and how gamification affects students' motivation. Content analysis of the students' opinions is presented in Table 1. 
Table 1. Student Views on the Implementation Process

\begin{tabular}{lll}
\hline \multicolumn{1}{c}{ Category } & \multicolumn{1}{c}{ Code } & $f$ \\
\hline Contribution of digital gamification to & Improving writing skills & 6 \\
writing process & Making fun & 4 \\
& Fun and educational & 3 \\
& Spelling and punctuation & 2 \\
& Improving your imagination & 2 \\
& Develop creativity & 2 \\
& Supporting the use of technology & 1 \\
& Interesting enhancement to the & 1 \\
& lesson & \\
& Productivity & 1 \\
& Overcoming boundaries & 1 \\
& Practicality gain & 1 \\
& Funny & 11 \\
Digital gamification perception & Interesting & 2 \\
& Fun and educational & 1 \\
Perception of digital gamification tool & Fun and educational & 4 \\
& Motivational & 1 \\
& Regular & 1 \\
& Suitable for the level & 1 \\
& Improving writing skills & 1 \\
& Taking time to enter the game & 1 \\
& Complex & 1 \\
& Accelerate writing process & 1 \\
& Cooperation & 1 \\
& Easy to use & 1 \\
& Attractiveness of the actors & 1 \\
&
\end{tabular}

As shown in Table 1, three different categories were established. The frequencies for each category were as follows: "Contribution of digital gamification to writing process," ( $f=24)$; "Digital gamification perception," ( $f=14)$; "Perception of digital gamification tool," ( $f=14)$. The most frequent code pertained to entertainment. The students who found the activity in the Turkish language teaching process entertaining made the following comments:

"I think it's better than lecturing. The boring lesson turned into entertainment." (Demir, semi-structured interview form).

"I enjoy this lesson so much. I feel very happy with myself in this lesson." (Seref, semistructured interview form).

"...because it is so nice that our teacher finds a good application for us and prints us amusing materials." (Ayse, semi-structured interview form)

"Everything is very beautiful. I like this lesson because it is a lesson that will entertain me." (Tulay, semi-structured interview form).

The students clearly found the lesson to be fun and compared it with their previous lectures, which they viewed negatively. With this application, the students were given a fun role to play. Other opinions about the instructive lessons are as follows. 
"I think it is necessary for us to do such a lesson because I am both learning and playing." (Ercan, semi-structured interview form).

"Yes because we have fun and learn better and more quickly." (Gulhan, semi-structured interview form).

"I think it is because I think learning will be more beneficial when it is amusing." (Aysenur, semi-structured interview form).

Notably, the application process did not incorporate the teaching function back into the course. Regarding the teaching side, the frequency values made the application fall under the highest category. The code related to the development of writing skills with the highest frequency value under the category of "Contribution to the teaching process in Turkish" was a teaching aspect of the application process.

Table 1 shows that some students formed negative opinions about the implementation process. These views are described as follows.

"The beginning of this game is very long and complicated, but the part of the story is very nice after it is ready." (Demir, semi-structured interview form).

"The Storium application is a nice but complicated application and does not have a feature like rearrangement." (Aydan, semi-structured interview form).

Demir complained about the waiting time for logging into the application. Aydan described the application as complicated. Both reflections were thought to have resulted from the fact that the application tool was an English interface.

\section{Discussion and Conclusion}

The purpose of this study was to determine the contribution of gamification to the development of writing skills of seventh grade students. Unlike the studies in the literature, this study was prepared an action plan on how digital gamification could be associated with writing skills. A content was presented in this action plan about how to use digital games which were not recommended in the Turkish Language Curriculum (2018) but which were thought to have an important place in students' daily lives. In this way, it was tried to determine the thoughts of how the gamification made by digital game serve the students' writing education and how they affected their motivation. An action plan was presented on how to improve the negative motivations of the students about writing education in the literature.

The aim of gamification was to make the teaching process more interesting for students (Kapp, 2012). Toward this aim, a lengthy application process in which qualitative data were collected intensively was realized. From the literature on Turkey, only the work of Genc Ersoy (2017) was included as it associated the Turkish language teaching process with the digital teaching process. Genc Ersoy (2017) concluded that digital gamification in their work increased the interest of the students and made the teaching process increasingly effective. This direction supported the results of the current study. Nevertheless, different working groups were formed in the present study. The working groups comprised seventh grade students, whereas those in the work of Genc Ersoy (2017) were composed of fourth grade students. The current work focused on writing skills, whereas Ersoy (2017) considered vocabulary only. This study differs from other studies in the literature in terms of its relation with gamification and writing education, which 
were complex for students (Demirel \& Sahinel, 2006) and thus developed negative attitudes (Maltepe, 2006; Ungan, 2007).

A number of studies (Cruaud, 2016; Figueroa Flores, 2015; Huner, 2018; Gellar-Goad, 2015; Karatekin, 2017; Rachels \& Rockinson-Szapkiw, 2018) related to the relationship between language arts and digital gamification generally centered on second language education. Other studies on the digital gamification of language arts in Turkey include those by Guasch, Espasa, Alvarez, and Kirschner (2013) and by Cook, Gremo, and Morgan (2017). The study conducted by Cook, Gremo, and Morgan (2017) with eighth grade students had common features related to the interest of the current study. They also integrated the writing process in their own work in a multidimensional way. However, in this study, gamification was dealt with in a different perspective from other studies in the literature. This difference was that it related the writing skills to the gamification in terms of the Turkish language education as a mother tongue.

The participants set out the subject, characters, barriers, and helping conditions on the basis of their preliminary knowledge and past experiences. In this way, the activities performed in the writing process revealed the participants' prior knowledge, and the content of the game presented information about the narrators. The same applied to the players. The responses during the movements and in the face of difficulties provided information about the players. The response of the students to the learning activities also served as a direct indication of their motivation (Glover, 2013). This information was based on interviews related to the daily life experiences of the participants. Games put emotions into action (Buckley \& Doyle, 2016). Therefore, the characteristics and experiences of each learner must be considered while the playout process is being applied (Kiryakova, Angelova, \& Yordanova, 2014). From this point of view, the actuation process clearly combined in-school and out-of-school life. It overlaped with the results of the work of Lee and Hammer (2011), which supported the result of the current study. Lee and Hammer (2011) described digital gamification as different. They stated that it could contribute to the daily life experiences of the students through the linking of the process of gamification with the teaching process. In this study, gamification was based on associating the daily life experiences of the students with the writing process in the classroom and thus motivating them. The data obtained from the study reveals this.

Digital gamification in the writing process was thought to facilitate classroom management. With the role of actors and narrators, the entire class was included in the digital authoring process. This feature ensured equal participation. Hence, the teaching process was considered highly efficient. Hibbard (2015), who proposed an active classroom environment to link play to the writing process, supported this end result. According to him, the writing process improved creativity. Students felt comfortable with digital gamification and are willing to try new things (Cahyani, 2016). In the process of creative writing, narrators present a problem in the text. Then, players made moves according to these problems to improve their problem-solving skills. This result was also supported by different studies (Kapp, 2012; Kayali \& Yilmaz, 2017; Ozer, Kanbul, \& Ozdamli, 2018; Urh, Vukovic, \& Jereb, 2015). Gee (2013) related such condition to the problem solving involved in game design. As a result of this study, it was concluded that the students' interest towards the lesson increased and fun for students thanks to the problem solving process offered by gamification.

It was seen that this fun content contributed to the development of writing skills. The research of El Tantawi, Sadaf, and AlHumaid (2018), which involved in the writing process of a different study group with the writing process, was to support the results of this research in order to improve its writing skills. Hibbard (2015), in his study, concluded that most of the students' 
writing skills developed to a certain extent. As a result of this research, the aspects contributed were to be careful about writing and punctuation and developing collaborative writing skills. Different studies in the literature (Buchinger \& SilvaHounsell, 2018; Halloluwa et al., 2018; Sánchez-Martín, Cañada-Cañada, \& Dávila-Acedo, 2017) showed that gamification supported collaborative work. Unlike many studies, Robson et al. (2015) stated that gamification was led to individual competition. However, it was thought that the writing process performed by gamification provided a content that was appropriate to the level. Similar studies (Gee, 2008; Kingsley \& Grabner-Hagen, 2015; Olson, 2010; Ozer, Kanbul, \& Ozdamli, 2018) showed that students were motivated, encouraged and provided an efficient teaching process. A study conducted by Lam, Hew, and Chiu (2018) concluded that gamification increased motivation to the writing process and students improved their writing skills. Mast (2017), on the other hand, stated that students could not maintain their motivation for a long period of time in relation to the gamification process.

\section{Recommendations}

The current study was conducted on the Authorship and Writing course. The teachers in the study were more liberal in terms of selecting this lesson over a traditional Turkish language lesson. To make this elective course useful and interesting for the students, teachers can prepare lesson plans that integrate the course process with digital gamification. If these plans are submitted to the schools by the Ministry of National Education, the teaching process can be realized effectively.

The learning outcomes of the application process constitute the learning outcomes of the Writing Turkish Language Curriculum (2018). The resulting product is a game developed in the form of a digital story. The application tool serves this purpose as well. As the research findings reveal, this text-creation process attracts students' attention. In this respect, it can be used as a narrative text type in Turkish language lesson.

During the writing process in this research, we obtained information about the students' prior knowledge and past experiences. The use of this application in the Turkish teaching process may facilitate the movement of the teaching period out of school. At this point, permanent behavior change can be realized and controlled with minimal effort.

We considered the individual differences of the students. Hence, the students discovered their strengths and weaknesses. According to their own characteristics, the most appropriate behavior could be understood. All students were actively involved in the teaching process. The application process can be made objective-oriented under the guidance of teachers. All students' high-level thinking skills can be developed in line with these goals.

\section{References}

Ayhan, S. \& Taner, A. (2016). Examination of students' perceptions about computer lessons carried out with gamification. Turkish Journal Of Computer And Mathematics Education, 7(3),553-577. doi:10.16949/turkbilmat.277871 
Baker, C., Davis, D., \& Dolgon, C. (2014). Toward a participatory imagination: Lessons on engagement from popular education and participatory action research. Farnham, UK: Ashgate.

Bal, M. (2018). Cok katmanli okuryazarlik baglaminda oyunlastirmanin Turkce ogretim surecine katkisi. Ana Dili Egitimi Dergisi, 6(1), 183-201.

Bogott, T. (2017). An exploration of technology integration using digital game-based learning with in early childhood settings. Retrieved on 26 February 2019 from https://search. proquest.com/docview $/ 1961180994$ ? accountid $=15340$

Bolat, Y. İ., Simsek, O., Ulker, U. (2017). Oyunlastirilmil çevrimiçi sinif yanitlama sisteminin akademik basariya etkisi ve sisteme yönelik gorusler. Abant Izzet Baysal Universitesi Egitim Fakultesi Dergisi, 17(4), 1741-1761.

Buchinger, D. \& da Silva Hounsell, M. (2018). Guidelines for designing and using collaborativecompetitive serious games. Computers \& Education, 118, 133-149. doi:10.1016/j. compedu.2017.11.007

Buckley, P. \& Doyle, E. (2016). Gamification and student motivation. Interactive Learning Environments, 24(6), 1162-1175.doi=10.1080/10494820.2014.964263

Cahyani, A. D. (2016). Gamification approach to enhance students engagement in studying language course. Matec Web of Conferences, 58(1), 1-6. doi:10.1051/matec5conf/ 2016803006

Cammarota, J., Romero, A., \& Stovall, D. (2014). Raza studies: The public option for educational revolution. Tucson, AZ: University of Arizona Press.

Chen, M. H., Tseng, W. T., \& Hsiao, T. Y. (2018). The effectiveness of digital game-based vocabulary learning: A framework-based view of meta-analysis. British Journal of Educational Technology, 49(1), 69-77.

Cohan, A. \& Honigsfeld, A. (2011). Breaking the mold of preservice and inservice teacher education: Innovative and successful practices for the twenty-first century. Lanham: Rowman \& Littlefield Education.

Cook, M. P.,Gremo, M. \& Morgan, R. (2017). We're just playing. Simulation \& Gaming, 48(2), 199-218. doi:10.1177/1046878116684570

Cózar-Gutiérrez, R. \& Sáez-López, J. (2016). Game-based learning and gamification in initial teacher training in the social sciences: an experiment with MinecraftEdu. International Journal Of Educational Technology In Higher Education, 13(1), 1-11. doi:10.1186/s41239016-0003-4

Creswell, J. W. (2013). Nitel arastirma yontemleri (Cev. M. Butun ve S. B. Demir). Ankara: Siyasal Kitabevi.

Cruaud, C. (2016). The play fulframe: Gamification in a French as a foreign language class. Innovation in Language Learning and Teaching, 12(4), 330-343. doi:10.1080/17501229. 2016. 1213268

Cibik, S. (2010). Oyunlastirma yoluyla islenen siirlerde parcalarustu birimlerin karsilastiriması (Yayimlanmamis yüksek lisans tezi). Mugla Sitki Kocman Universitesi Sosyal Bilimler Enstitusu.

Demirel, O. \& Sahinel, M. (2006). Turkce ogretimi. Ankara: Pegem. 
Denham, A. (2018). Using a digital game as an advance organizer. Educational Technology Research and Development, 66(1), 1-24. doi:10.1007/s11423-017-9537-y

El Tantawi, M., Sadaf, S., \& Al Humaid, J. (2018). Using gamification to develop academic writing skills in dental undergraduate students. European Journal of Dental Education, 22(1), 15-22. doi.org/10.1111/eje.12238

Ferguson, P. B., McNiff, J., \& Whitehead, J. (2000). Collaboration for co-liberation. In J. McNiff (Ed.), Action research in organisations (pp. 115-124). Milton Park. Routledge.

Fettes, T. (2007). A case for action? Skills for active citizenship research. London: Quality Improvement Agency.

FigueroaFlores, J. F. (2015). Using gamification to enhance second language learning. Digital Education Review, 27, 32-54.

Fis Erumit, S. (2016). Oyunlastirma yaklasimlarinin eğitimde kullanimi: Tasarim tabanli bir arastirma (Yayimlanmamis doktora tezi). Ataturk Universitesi Egitim Bilimleri Enstitusu, Erzurum.

Gee, J. P. (2008). Learning and games. In K. Salen (Ed.), The ecology of games: Connecting youth, games, and learning (pp. 21-40). Cambridge, MA: The MIT Press.

Gee, J. P. (2013). Games for learning. Educational Horizons, 91(4), 16-20.

Gellar-Goad, T. (2015). World of Wordcraft: Foreign language grammar and composition taught as a term-long role-playing game. Arts and Humanities in Higher Education, 14(4), 368-382. doi:10.1177/1474022214556030

Genc Ersoy, B. (2017). Turkce dersinde oyunlastirmanin ilkokul ogrencilerinin soz varligina ve motivasyonlarina etkisi (Yayimlanmamis doktora tezi). Anadolu Universitesi Egitim Bilimleri Enstitusu, Eskişehir.

Glover, I. (2013). Play as you learn: Gamification as a technique for motivating learners. In A. Couros \& V. Irvine (Eds.) Proceedings of World Conference on Educational Multimedia, Hypermedia and Telecommunications (pp. 1999-2008). Chesapeake, VA: AACE.

Gocer, A. (2014). Yazma tutum olcegi'nin (YTO) Turkceye Uyarlanmasi: Gecerlik ve guvenirlik calismasi. Kastamonu Egitim Dergisi, 22(2), 515-524.

Gocer, A. (2010). Turkce öğretiminde yazma egitimi. Uluslararası Sosyal Araştirmalar Dergisi, 3(12), 178-194.

Gogus, B. (1978). Orta dereceli okullarimizda Turkce ve yazin egitimi. Ankara: Kadıoglu Matbaacilik.

Guasch, T., Espasa, A., Alvarez, I.M., \& Kirschner, P. A.(2013). Effects of feedback on collaborative writing in an online learning environment. Distance Education, 34(3), 324338. doi:10.1080/01587919.2013.835772.

Halloluwa, T.,Vyas, D., Usoof, H., \& Hewagamage, K. P. (2018). Gamification for development: A case of collaborative learning in Sri Lankan primary schools. Personal and Ubiquitous Computing, 22(2), 391-407.do 10.1007/s00779-017-1073-6

Hazar, Z.,Tekkursun Demir, G., \& Dalkiran, H. (2017). Ortaokul ogrencilerinin geleneksel oyun ve dijital oyun algilarinin incelenmesi: Karsilastirmali metafor calismasi. Ankara Universitesi Beden Egitimi ve Spor Yuksekokulu Spormetre Beden Egitimi ve Spor Bilimleri Dergisi, 15(4), 179-190. 
Hibbard, L. (2015). Battling with monsters: Integrated gamification in the first year composition classroom. Retrieved on 26 February 2019 from https://search.proquest.com/docview/ 1678945478 ? accountid $=15340$

Homer, B. D., Raffaele, C., Ober, T. M., Plass, J. L., \& Ali, A. (2018). Improving high school students' executive functions through digital gameplay. Computers \& Education, 117, 50-58. doi.org/10.1016/j.compedu.2017.09.011

Huner, O. (2018). Oyunlastirmanin ikinci dil egitiminde akademik başari ve motivasyon uzerine olan etkileri. (Yayimlanmamis yuksek lisans Tezi). Bahcesehir Universitesi, Egitim Bilimleri Enstitusu, Istanbul.

Johnson, A. P. (2014). Eylem araştırması el kitabı (Cev. Y. Uzuner ve M. Ö. Anay). Ankara: Ani.

Johnson, A.P. (2005). A short guide to action research. Boston, MA: Pearson Education.

Kalkan, A. (2016). 3B sanal dunyalarda oyunlastirmanin ortaokul 5. sinif ogrencilerinin başari, akis ve tutumlarina etkisinin arastirilmasi. (Yayimlanmamis yuksek lisans tezi). Ataturk Universitesi Egitim Bilimleri Enstitusu, Erzurum.

Kapp, K. M. (2012). The gamification of learning and instruction: Game-based methods and strategies for training and education. San Francisco, CA: John Wiley \& Sons.

Karagiorgas, D. N. \& Niemann, S. (2017). Gamification and game-based learning. Journal of Educational Technology Systems, 45(4), 499-519.

Karatas, E. (2015). Gamification in education: Research trends. Kirsehir Egitim Fakultesi Dergisi, 15(2), 315-333.

Karatekin, i. (2017). Yeni başlayanlar icin yabanci dilde kelime bilgisi ogretiminde oyunlaştirmanin kullanimi. (Yayimlanmamis yuksek lisans tezi). Cag Universitesi Sosyal Bilimler Enstitusu. Mersin.

Kayali, S. \& Yilmaz, M. (2017). An exploratory study to assess analytical and logical thinking skills of the software practitioners using a gamification perspective. Suleyman Demirel Universitesi Fen Bilimleri Enstitusu Dergisi, 21(1), 178-189.. doi:10.19113/sdufbed.39411

Kemmis, S., McTaggart, R., \& Nixon, R. (2014). The action research planner: Doing critical participatory action research. London: Springer International.

Khan, A., Ahmad, F. H., \& Malik, M. M. (2017). Use of digital game based learning and gamification in secondary school science: The effect on student engagement, learning and gender difference. Education and Information Technologies, 22(6), 2767-2804.

Kingsley, T. L. \& Grabner-Hagen, M. M. (2015). Gamification. Journal of Adolescent \&Adult Literacy, 59(1), 51-61.https://doi.org/10.1002/jaal.426

Kingsley, T. L. \& Grabner-Hagen, M. M. (2018). Vocabulary by gamification. Reading Teacher, 71(5), 545-555. doi:10.1002/trtr.1645

Kiryakova, G., Angelova, N., \& Yordanova, N. (2014). Gamification in education. In Proceedings of 9th International Balkan Education and Science Conference. Edirne: Trakya University.

Kocadere, S. A., Caglar, S. \& Simsek, N. (2015). Cevrimici ogrenme ortamlarinda oyunlastirma. Journal of Educational Sciences \& Practices, 14(27), 83-102.

Lam, Y. W., Hew, K. F., \& Chiu, K. F. (2018). Improving argumentative writing: effects of a blended learning approach and gamification. Language Learning \& Technology, 22(1), 97-118. 
Lee, J. J. \& Hammer, J. (2011). Gamification in education: what, how, why bother? Academic Exchange Quarterly, 15(2), 1-5.

Lincoln, Y.S. \& Guba, E.G. (1985). Naturalisticlnquiry. Beverly Hills, CA: Sage.

Maltepe, S. (2006). Turkce ogretiminde yazili anlatim uygulamalari icin bir secenek: Yaratici yazma yaklasimi. Ankara Universitesi Dil Dergisi, 132, 56-66.

Mast, E. (2017). The gamification of an online english composition course: An action research exploration of student motivation and engagement. Retrieved on 26 February 2019 from https://search.proquest.com/docview/1946680557?accountid=15340

McNiff, J. \& Whitehead, J. (2006). All you need know about action research. Beverly Hills, CA: Sage.

Merriam, S. B. (2013). Nitel arastirma desen ve uygulama icin bir rehber (Cev. S. Turan). Ankara: Nobel.

Miles M. \& Huberman, M. (1994). An expanded source book qualitative data analysis (2nd. ed.). Beverly Hills, CA: Sage.

Milli Egitim Bakanligi [MEB]. (2018). Turkce dersi ogretim programi (1-8. siniflar). Ankara: MEB Talim Terbiye Kurulu Baskanligi.

Milli Egitim Bakanligi [MEB]. (2006). Ilkogretim 6-8. sinif Turkce ogretim programi. Ankara: MEB Talim Terbiye Kurulu Baskanligi.

Newzoo. (2017). The global games market will reach \$108.9 billion in 2017 with mobile taking 42\%". Retrieved on 26 February 2019 from https://newzoo.com/

Newzoo. (2017). The Turkish gamer, 2017. Retrieved on 26 February 2019 from https://newzoo.com/

Nolan, J. \& McBride, M. (2013). Beyond gamification: re-conceptualizing game-based learning in early childhood environments. Information Communication and Society, 17(5), 594608. doi:10.1080/1369118X.2013.808365

Olson, C. K. (2010). Children's motivations for video game play in the context of normal development. Review of General Psychology, 14(2), 180-187. doi: 10.1037/a0018984

Ozer, H. H., Kanbul, S., \& Ozdamli, F. (2018). Effects of the gamification supported flipped classroom model on the attitudes and opinions regarding game-coding education. International Journal of Emerging Technologies in Learning (iJET), 13(1), 109123.https://doi.org/10.3991/ijet.v13i01.7634

Ozgur, H., Cuhadar, C., \& Akgun, F. (2018). Current trends in gamification research in education. Kastamonu Egitim Dergisi, 99, 1-9. do:: 10.24106/kefdergi.380982

Ozturk, S. (2015). Using gamification in effective team planning and team activity. (Unpublished master's thesis). Bahcesehir University Graduate School of Science. Istanbul.

Patton, M. Q. (2014). Nitel arastirma ve degerlendirme yontemleri (Cev. M. Butun \& S. B. Demir). Ankara: Pegem Akademi.

Pesare, E., Roselli, T., Corriero, N., \& Rossano, V. (2016). Game-based learning and gamification to promote engagement and motivation in medical learning contexts. Smart Learning Environments, 3(1), doi:10.1186/s40561-016-0028-0 
Piller, Y. (2016). Factors influencing parental attitudes toward digital game-based learning Retrieved on 26 February 2019 from https://search.proquest.com/docview/ 1871265364 ? accountid $=15340$

Polat, Y. (2014). Bir vaka incelemesi: Oyunlastirma yontemi ve Ingilizce ogrencilerinin motivasyonu uzerine etkisi. (Yayinlanmamis yuksek lisans tezi). Cag Universitesi, Mersin.

Prensky, M. (2007). Digital game-based learning. New York: McGraw-Hill.

Rachels, J. R. \& Rockinson-Szapkiw, A. J. (2018). The effects of a mobile gamification app on elementary students' spanish achievement and self-efficacy. Computer Assisted Language Learning, 31(1), 72-89.

Robson, K., Plangger, K., Kietzmann, J. H., McCarthy, I., \&Pitt, L. (2015). Is it all a game? Understanding the principles of gamification. Business Horizons, 58(4), 411-420. doi:10.1016/j.bushor.2015.03.006

Rugoero, D. \& Green, L. (2017). Problem solving through digital game design: A quantitative content analysis. Computers in Human Behavior, 73, 28-37. doi: https://doi.org/ 10.1016/j.chb.2017.03.024

Sánchez-Martín, J.,Cañada-Cañada, F., \& Dávila-Acedo, M. A. (2017). Just a game? Gamifying a general science class at university: Collaborative and competitive work implications. Thinking Skills \& Creativity, 26, 51-59. doi:10.1016/j.tsc.2017.05.003

Sari, A. \& Altun, T. (2016). Oyunlaştırma yontemi ile islenen bilgisayar derslerinin etkililigine yonelik ogrenci goruslerinin incelenmesi. Turkish Journal of Computer \& Mathematics Education, 7(3), 553-577. doi: 10.16949/turkbilmat.277871

Sever, S. \& Bical, A. (2018). Use of game elements in gamification: a case study on adidas micoach, khan academy, superbetter and swarm applıcatıons. Erciyes Iletisim Dergisi, 5(3), 216-236.

Sezgin, S., Bozkurt, A., Yılmaz, E. A., \& Linden, N.V.D. (2018). Oyunlastirma, egitim ve kuramsal yaklasimlar: Ogrenme sureslerinde motivasyon, adanmsilik ve surdurulebilirlik. Mehmet Akif Ersoy Universitesi Egitim Fakultesi Dergisi, (45), 169-189.

Storium. (2018). Storium. Retrieved on 29 November 2018 from https://storium.com/

Stringer, E. T., Christensen, L. M., \& Baldwin, S. C. (2010). Integrating teaching, learning, and action research: Enhancing instruction in the K-12 classroom. Beverly Hills, CA: Sage.

Sung, H. \& Hwang, G. (2018). Facilitating effective digital game-based learning behaviors and learning performances of students based on a collaborative knowledge construction strategy. Interactive Learning Environments, 26(1), 118-134. Retrieved on 26 February 2019 from https://doi.org/10.1080/10494820.2017.1283334

Sahin, M. C. \& Namli, N. A. (2016). Gamification and effects on students' science lesson achievement. International Journal on New Trends in Education \& Their Implications (IJONTE), 7(1), 41-47.

Sahin, M. \& Samur, Y. (2017). Dijital cagda bir ogretim yontemi: Oyunlaştırma. Ege Egitim Teknolojileri Dergisi, 1(1), 1-27.

Sahin, Y. L., Karadag, N., Bozkurt, A., Dogan, E., Kilinc, H., Ugur, S., Gumus, S., Ozturk, A. \& Guler, C. (2017). The use of gamification in distance education: A web-based gamified quiz application. Turkish Online Journal of Qualitative Inquiry, 8(4), 372-395.

doi:10.17569/tojqi.329742 
Taskin, N. \& Cakmak, E. K. (2017). Ogrenci merkezli ogrenme ortamlarinda oyunlaştirmanin alternatif degerlendirme amacli kullanimi. Bartin Universitesi Egitim Fakultesi Dergisi, 6(3), 1227-1248. doi:10.14686/buefad.333286

Tomal, D. R. (2003). Action research for educators. Lanham, MD: Scarecrow Press.

Tompkins, G. E. (1982). Seven reasons why children should write stories. Language Arts, 59(7), 718-21.

Ungan, S. (2007).Yazma becerisinin gelistirilmesi ve onemi. Dumlupinar Universitesi Sosyal Bilimler Enstitusu Dergisi, 23(2), 461-472

Urh, M., Vukovic, G., \& Jereb, E. (2015). The model for introduction of gamification into elearning in higher education. Procedia-Social and Behavioral Sciences, 197, 388-397. doi.org/10.1016/j.sbspro.2015.07.154

Vaughan, M. \& Burnaford, G. (2016). Action research in graduate teacher education: A review of the literature 2000-2015. Educational Action Research, 24(2), 280-299. doi:10.1080/ 09650792.2015 .1062408

Werbach, K. \& DanHunter. (2012). For the win: How game thinking can revolutionizeyour business. Philedelphia, PA: Wharton Dijital Editions.

Yapici, I. U. \& Karakoyun, F. (2017). Gamification in biology teaching: A sample of kahoot application. Turkish Online Journal of Qualitative Inquiry, 8(4), 396-414. doi:10.17569/tojqi.335956

Yildirim, A. \& Simsek, H. (2013). Sosyal bilimlerde nitel arastirma yontemleri (9. baski.). Ankara: Seckin.

Yildirim, I. \& Demir, S. (2016). Students' views about gamification based curriculum for the lesson of "Teaching Principles and Methods". Uluslararası Egitim Programlari ve Ogretim Calismalari Dergisi, 6(11), 85-101.

Yildirim, I. \& Demir, S. (2014). Oyunlastirma ve Egitim. International Journal of Human Sciences, 11(1), 655-670. doi:10.14687/ijhs.v11i1.2765

Zireva, D. (2017). Cul-De-Sac from diehard traditions: The demise of action research in teacher education. Educational Research And Reviews, 12(15), 725-731.

Correspondence: Mazhar Bal, Ph.D., Department of Turkish Language Teaching, Akdeniz University, Antalya, Turkey 